\title{
A Bibliometric Analysis and Visualisation of Research Trends in Health Issues of Nickel- Implants
}

\author{
Nishant Ranjan ${ }^{\text {a }}$ \\ Department of Mechanical Engineering, Chandigarh University, Gharuan, \\ Punjab,India. 140413
}

Article History: Received: 11 January 2021; Accepted: 27 February 2021; Published online: 5 April 2021

\begin{abstract}
Nickel toxicity is one of the major challenges of Nickel-based implants. The bibliometric analysis had been conducted to understand the active authors, organizations, journals, and countries involved in the research domain of "Health issues of Nickel-implants". All published articles related to "Health Issues of Nickel-implants" from "Scopus", were analyzed using the VOS viewer to develop analysis tables and visualization maps. This article had set the objective to consolidate the scientific literature regarding "Health Issues of Nickel-implants" and also to find out the trends related to the same. The most active journal in this research domain was the Journal of Biomedical Materials Research. The most active country was the United States of America. The leading organization engaged in the research regarding allergy of Nickel-implants was the Rush University Medical Center of United States of America. The most active authors who had made valuable contributions related to the toxicity of Nickel implants were Hallab N.J and Savarino I
\end{abstract}

Keywords: Nickel-implants, Health issues, Material engineering, Bibliometric analysis, VOS viewer,

\section{Introduction}

An engineered medical device to replace a missing or damaged biological structure is known as an implant. Nickel is one of the widely used metals for diversified implants. The various adverse effects of Nickel implants are described (Nwashindi and Dim, 2014). Similarly, several Nickel based alloys were being used for surgical implants (Cahoon and Hill, 1978)(Er and Unsaldi, 2013)(Li et al., 2014)(Marek and Treharne, 1982)(Mikhailov, 2002). The major health issues related to Nickel implants are the toxicity of the metal, failure of nickel implants, and allergy or hypersensitivity. Material engineering and surface engineering play a very important role in providing solutions to diversified issues connected with toxicity, allergy, and failure of Nickel-based implants (Nagaraja et al., 2017)(Ozkomur, Erbil, and Akova, 2013). The toxicity of Nickel implants is a serious issue to be addressed for the safe usage of Nickel-based implants.

The toxicity of Nickel-based implants may cause allergy, high metal content in blood, and other issues. Nickelbased implants can trigger allergy or hypersensitivity, especially with orthopedic implants (Guccione and Jacob, 2018). The toxicity of Nickel can also be through the wear of Nickel-based implants. The allergy or hypersensitivity can be e type IV/delayed-type hypersensitivity reactions (Bjurholm et al., 1990)(Baumann and Crist, 2020). The hypersensitivity to implants is found on the insertion of intravascular stents, dental implants, cardiac pacemakers, and implanted gynecologic devices (Basko-Plluska, Thyssen, and Schalock, 2011). There are pieces of evidence for a higher Prevalence of Nickel and Palladium hypersensitivity in Patients with Ulcerative Colitis (Kageyama et al., 2020). Allergy of Nickel implants had been reported regarding hip implants (Thomas et al., 2009) Allergy of Nickel-based total hip arthroplasty (Thomsen, Rozak and Thomas, 2013). The common type of allergy caused by Nickel-based implants is allergic contact dermatitis. Nickel-induced systemic contact dermatitis (Bibas et al., 2013). Cases of acute dermatitis due to Nickel allergy were reported (Grimalt and Romaguera, 1980) hand dermatitis due to Nickel-based implants (Kanerva and Förström, 2001) dermatitis due to Nickel based Ortho implants (Rostoker et al., 1986).

Future research can be on research niches of researching on allergic issues due to Nickel-based implants, measures for reducing the toxicity of Nickel-based implants. Metal allergies cannot be ignored carelessly as Metal hypersensitivity is the cause of chronic fatigue syndrome (Manousek, Privarova, and Pavkova-Goldbergova, 2014). This bibliometric analysis will be a useful platform for future researchers by realizing the top researchers, organizations, and countries involved in research regarding allergy related to Nickel based-implants. This article is arranged into four sections. The first section is the introduction, followed by the discussion of the methodology by which the research was conducted. The third section deals with results and discussion. The fourth section deals with the conclusion. The following research objectives and research questions were framed for conducting bibliometric analysis systematically.

\subsection{Research Objectives}

a) To consolidate the literature regarding Health Issues of Nickel-implants

b) To find out the trends related to research in Health Issues of Nickel-implants 


\subsection{Research Questions}

a) Who are the active researchers working on the Health Issues of Nickel-implants?

b) Which are the main organizations and countries working on the Health Issues of Nickel-implants?

c) Which are the main journals related to an Health Issues of Nickel-implants?

\section{Research Methodology}

Scopus files had been used for this article. For the article selection, the Boolean used was TITLE-ABS (Toxicity of Nickel-implants) on 02/03/2021. All the tables in this paper were created by using Microsoft Excel and VOS Viewer. Grammarly was used for spelling and grammar checks. Mendeley was used for article review and citation. This paper had been inspired by bibliometric analysis in its presentation style, analysis, and methodology from the works (Farhat et al., 2013; Liao et al., 2016; Kolkailah et al., 2019; Rodríguez-Padial et al., 2019; Tran et al., 2019; Ullah et al., 2019; Shahid et al., 2020).

\section{Results and discussion}

\subsection{Results}

This first round of search produced an outcome of 136 documents, in five languages, out of which 126 documents were in English. The classification of document categories is shown in Figure 1. For improving the quality of the analysis, we had selected only the peer-reviewed articles and all other documents had not been considered. Thus after using filters "Article" and "English" the second round search produced an outcome of 84 English articles (both open access and others) and had been used to conduct bibliometric analysis and visualization using VOS Viewer. The English research articles in this domain since 1976 had been shown in Figure 2.

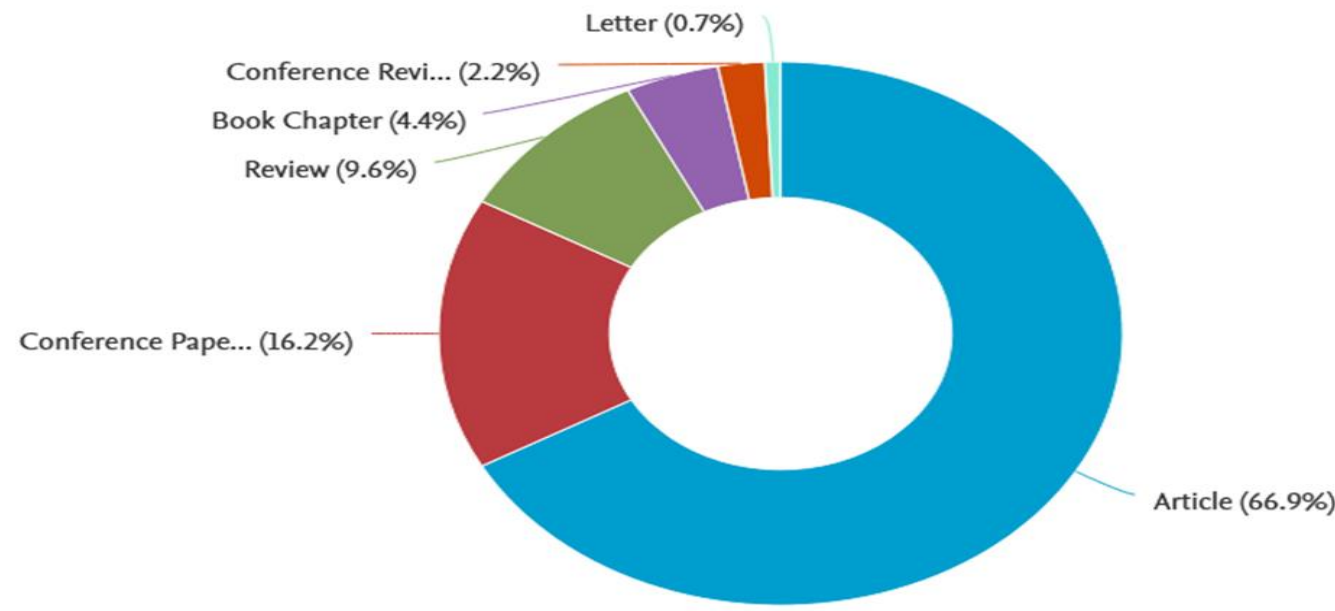

Figure 1: Classification of the documents on "Health Issues of Nickel-implants", Source: www.scopus.com

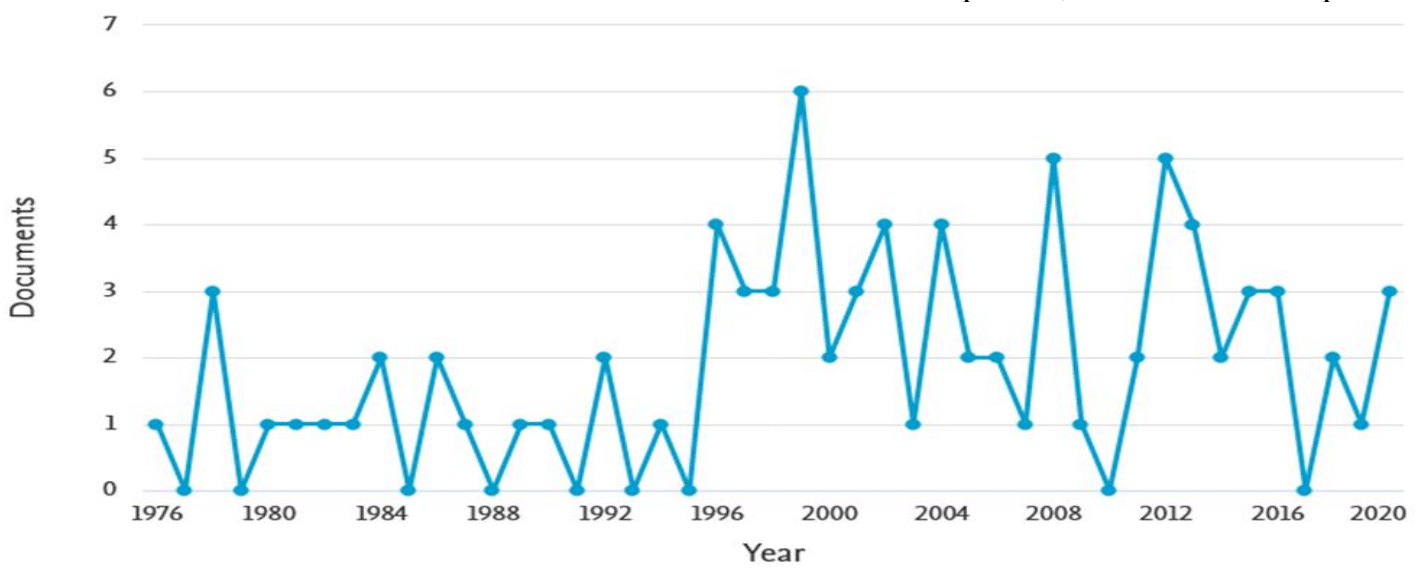

Figure 2: Period wise publication of articles, Source: WWW.scopus.com

Co-authorship analysis of top authors had been shown in figure 3. For a better presentation of the analysis, the parameters used were the minimum number of documents of an author as two and the minimum number of citations of authors as one. This combination plotted the map of thirty-three authors, in 10 clusters. The overlay visualization map of co-authorship analysis plotted in Figure 3, points out the major researchers with their strong co-authorship linkages and clusters involved. 


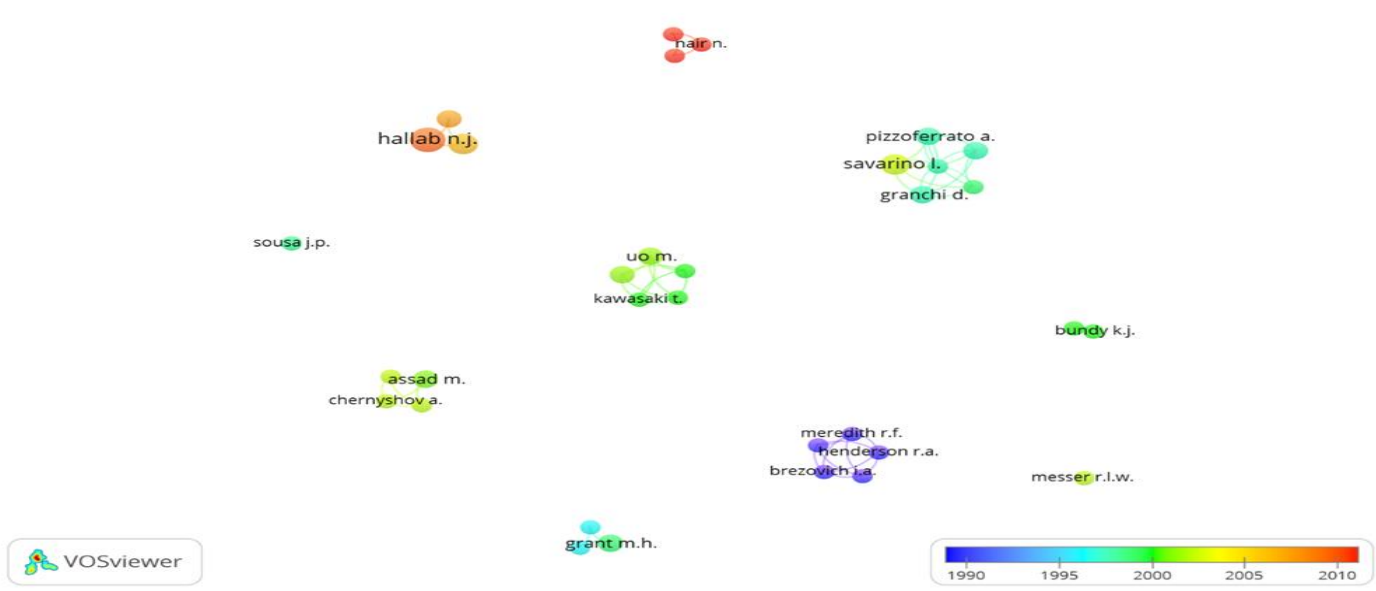

Figure 3: Co-authorship analysis on basis of authors

The citation analysis of top authors had been shown in table 1, along with co-authorship links. For the citation analysis, the parameters used were the minimum number of documents of an author as one and the minimum citations of an author as two.

Table 1: Highlights of most active authors

\begin{tabular}{|c|r|r|r|r|r|}
\hline Description & Authors & Documents & Citations & $\begin{array}{c}\text { Average } \\
\text { citations per } \\
\text { documents }\end{array}$ & $\begin{array}{r}\text { Link } \\
\text { strength }\end{array}$ \\
\hline $\begin{array}{c}\text { Authors with the } \\
\text { highest publication, } \\
\text { citations }\end{array}$ & Hallab N.J & 6 & 394 & 66 & 18 \\
\hline $\begin{array}{l}\text { Authors with the } \\
\text { highest co-authorship } \\
\text { links }\end{array}$ & Savarino I & 4 & 165 & & \\
\hline
\end{tabular}

In Co-occurrence analysis, we had used all keyword analyses, by keeping the minimum number of occurrences of a keyword as 15 . This combination plotted the map of 30 thresholds, in three clusters. The overlay visualization of co-occurrence analysis of keywords has been shown in Figure 4.

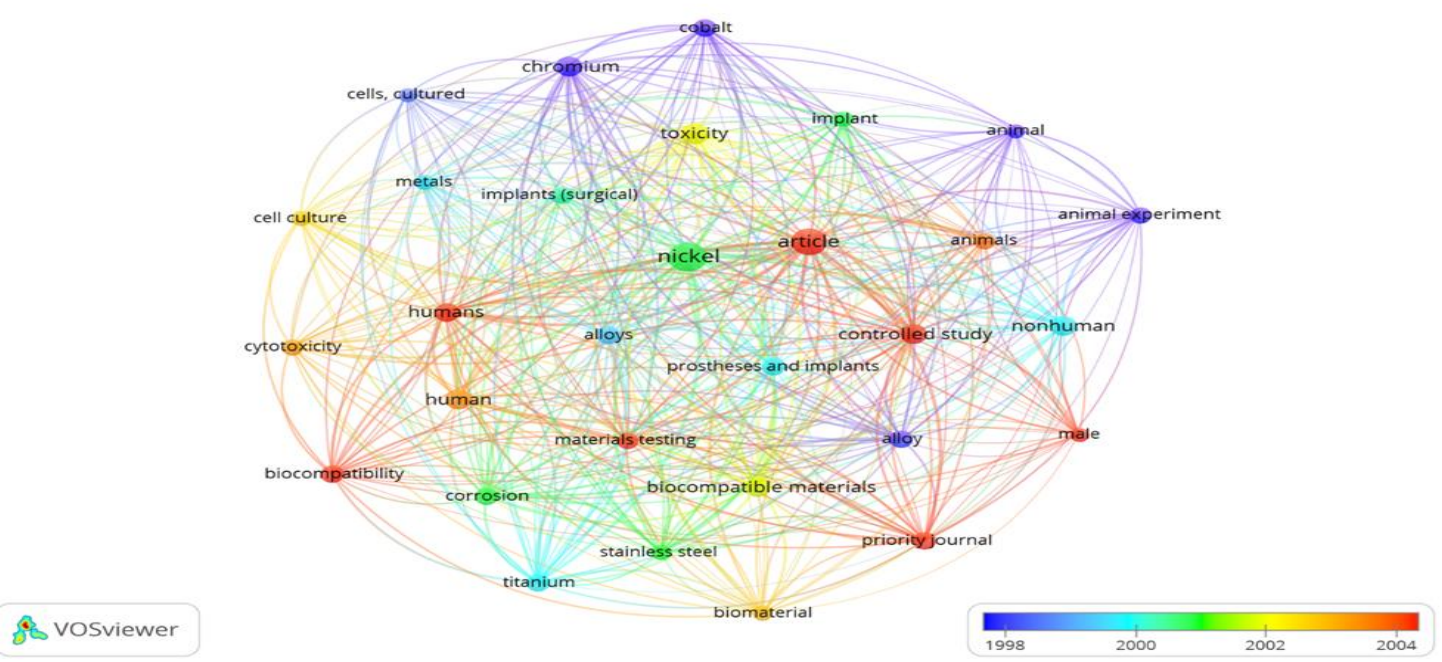

Figure 4: Co-occurrence analysis on basis of all keywords

The leading organizations engaged in research on "Health Issues of Nickel-implants" had been found out by the volume of publications and citation analysis, the parameters used are the minimum number of documents of an organization as one and the minimum number of citations of organizations as one. The leading organization in the research regarding "Health Issues of Nickel-implants", with the highest number of publications and citations, was the Rush University Medical Center of United States of America Table 2: Highlights of the most active organization

\begin{tabular}{|l|l|l|l|l|}
\hline Organizations & Country & Document & Citatio & $\begin{array}{l}\text { Average } \\
\text { Citations } \\
\text { per } \\
\text { document }\end{array}$ \\
\hline
\end{tabular}


Rush University Medical Center

United States

Co-authorship analysis of the countries engaged in the research on "Health Issues of Nickel-implants" had been shown in Figure 5. The overlay visualization map of co-authorship analysis plotted in Figure 5, points out the main countries with their strong co-authorship linkages and clusters involved.

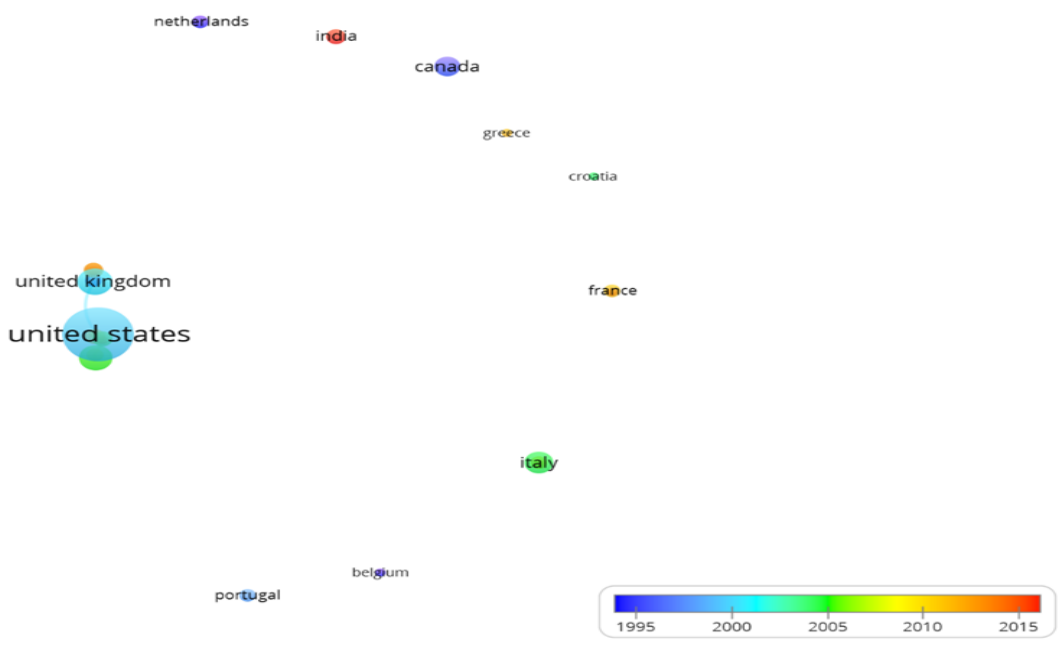

Figure 5: Co-authorship analysis on basis of countries

The citation analysis of top countries had been shown in table 3, along with co-authorship links. For the citation analysis, the parameters used were the minimum number of documents of a country as one and the minimum citations of the country as one.

Table 3: Highlights of Active Countries

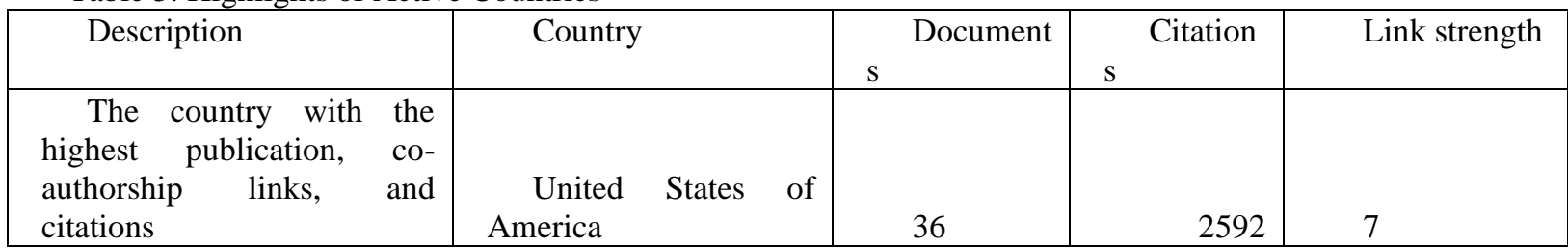

The most active countries in this research domain were the United States of America with the highest number of publications, Citations, and co-authorship links.

Link analysis and citation analysis were used to identify the most active journal in this research domain. We have taken the parameters of the minimum number of documents of a journal as one and the minimum number of citations of a journal as one for the link analysis and citation analysis. Highlights of the most active and relevant journals related to "Health Issues of Nickel-implants" are shown in table 4. Table 4 shows the journal activity of this research domain through parameters of publication volume, citations, and co-authorship linkages.

Table 4: Analysis of journal activity

\begin{tabular}{|c|c|r|r|r|r|}
\hline Description & Journal details & Documents & Citations & $\begin{array}{c}\text { Average } \\
\text { citations } \\
\text { per } \\
\text { documents }\end{array}$ & $\begin{array}{c}\text { Co- } \\
\text { authorship } \\
\text { links }\end{array}$ \\
\hline $\begin{array}{c}\text { Journal with the } \\
\text { highest publications, } \\
\text { citations, and links }\end{array}$ & $\begin{array}{l}\text { Journal of } \\
\text { Biomedical } \\
\text { Materials } \\
\text { Research }\end{array}$ & 17 & 1281 & & \\
\end{tabular}

From the above discussion regarding the bibliometric patterns in the research regarding the health issues of Nickel-implants of Nickel-implants, this research had observed a gradual increase in research interest regarding the health issues of Nickel-implants from the starting of the millennium and the momentum is going on positively. This points out the relevance and potential of this research domain (Refer to Figure 2). The most active author in this research domain Hallab N.J and Savarino I with the highest publication and citations; and co-authorship links respectively (Refer to table 1). The overlay analysis of top countries researching the toxicity of Nickel implantations indicates that the United States of America was the leading country relating to the highest number of publications, citations, and co-authorship links (Refer to figure 5). The top journals of this research domain were identified as the Journal of Biomedical Materials Research. From these wide sources of information, researchers 
can focus on top journals where they can identify the most relevant and highly cited articles regarding the toxicity of Nickel-implants.

\section{Conclusion}

Toxicity of Nickel-implant was an interesting research domain and the most active journal related to this research domain was the Journal of Biomedical Materials Research. The most active country was the United States of America. The leading organization engaged in the research regarding allergy of Nickel-implants was the Rush University Medical Center of United States of America. The most active authors who had made valuable contributions related to the toxicity of Nickel implants were Hallab N.J and Savarino I with the highest publication and citations; and co-authorship links respectively. This research domain offers a new avenue for researchers and future research can be on innovations in the health issues of Nickel-implants.

\section{References}

1. Basko-Plluska, J. L., Thyssen, J. P. and Schalock, P. C. (2011) 'Cutaneous and systemic hypersensitivity reactions to metallic implants', Dermatitis, 22(2), pp. 65-79. doi: 10.2310/6620.2011.10055.

2. Baumann, C. A., and Crist, B. D. (2020) 'Nickel allergy to orthopedic implants: A review and case series', Journal of Clinical Orthopaedics and Trauma. Elsevier B.V., 11, pp. S596-S603. doi: 10.1016/j.jcot.2020.02.008.

3. Bibas, N. et al. (2013) 'Nickel-induced systemic contact dermatitis and intratubal implants: The baboon syndrome revisited', Dermatitis. Lippincott Williams and Wilkins, 24(1), pp. 35-36. doi: 10.1097/DER.0b013e31827cd32e.

4. Bjurholm, A. et al. (1990) 'the lymphocyte response to nickel salt in patients with orthopedic implants', Acta Orthopaedica. Informa Healthcare, 61(3), pp. 248-250. doi: 10.3109/17453679008993510.

5. Cahoon, J. R., and Hill, L. D. (1978) 'Evaluation of a precipitation-hardened wrought cobalt-nickelchromium-titanium alloy for surgical implants', Journal of Biomedical Materials Research, 12(6), pp. 805821. doi: 10.1002/jbm.820120604.

6. Er, Y. and Unsaldi, E. (2013) 'The production of nickel-chromium-molybdenum alloy with open-pore structure as an implant and the investigation of its biocompatibility in vivo', Advances in Materials Science and Engineering, 2013. doi: 10.1155/2013/568479.

7. Farhat, T. et al. (2013) 'Research in congenital heart disease: A comparative bibliometric analysis between developing and developed countries', Pediatric Cardiology, 34(2), pp. 375-382. doi: 10.1007/s00246-0120466-6.

8. Grimalt, F. and Romaguera, C. (1980) 'Acute nickel dermatitis from a metal implant', Contact Dermatitis, 6(6), pp. 441-447. doi: 10.1111/j.1600-0536.1980.tb04992.x.

9. Guccione, J. P. and Jacob, S. E. (2018) 'Metal hypersensitivity in the context of connective tissue disease - An opportunity for practice prevention', Environmental Research. Academic Press Inc., 165, pp. 322323. doi: 10.1016/j.envres.2018.05.014.

10. Kageyama, Y. et al. (2020) 'Higher Prevalence of Nickel and Palladium Hypersensitivity in Patients with Ulcerative Colitis', International Archives of Allergy and Immunology. S. Karger AG, 181(6), pp. 456461. doi: 10.1159/000506633.

11. Kanerva, L. and Förström, L. (2001) 'Allergic nickel and chromate hand dermatitis induced by orthopedic metal implant', Contact Dermatitis. Blackwell Publishing Ltd, 44(2), pp. 103-104. doi: 10.1034/j.16000536.2001.4402096.x.

12. Kolkailah, A. A. et al. (2019) 'Bibliometric Analysis of the Top 100 Most Cited Articles in the First 50 Years of Heart Transplantation', American Journal of Cardiology. Elsevier Inc., 123(1), pp. 175-186. doi: 10.1016/j.amjcard.2018.09.010.

13. Li, J. et al. (2014) 'Low elastic modulus titanium-nickel scaffolds for bone implants', Materials Science and Engineering C, 34(1), pp. 110-114. doi: 10.1016/j.msec.2013.08.043.

14. Liao, J. et al. (2016) 'The most cited articles in coronary heart disease: A bibliometric analysis between 1970 and 2015', International Journal of Cardiology. Elsevier Ireland Ltd, 222, pp. 1049-1052. doi: 10.1016/j.ijcard.2016.08.002.

15. Manousek, J., Privarova, L. and Pavkova-Goldbergova, M. (2014) Metal hypersensitivity as the cause of chronic fatigue syndrome: Case report, Chronic Fatigue Syndrome: Risk Factors, Management, and Impacts on Daily Life. Nova Science Publishers, Inc. Available at: https://www.scopus.com/inward/record.uri?eid=2-s2.084947602632\&partnerID=40\&md5=95d8418d849a9c6d5ec7bb3fc7599979.

16. Marek, M. and Treharne, R. W. (1982) 'An in vitro study of the release of nickel from two surgical implant alloys', Clinical Orthopaedics and Related Research, No. 167, pp. 291-295. doi: 10.1097/00003086198207000-00045.

17. Mikhailov, O. V (2002) 'Complexation of nickel(II) with dioximes in Ni2[Fe(CN) 6] gelatin-immobilized matrix implants', Russian Journal of Coordination Chemistry/Koordinatsionnaya Khimiya, 28(5), pp. 352357. doi: 10.1023/A:1015573301672. 
18. Nagaraja, S. et al. (2017) 'Current practices in corrosion, surface characterization, and nickel leach testing of cardiovascular metallic implants', Journal of Biomedical Materials Research - Part B Applied Biomaterials. John Wiley and Sons Inc., 105(6), pp. 1330-1341. doi: 10.1002/jbm.b.33630.

19. Nwashindi, A. and Dim, E. M. (2014) 'Adverse effects of nickel in transosseous wires and surgical implants: literature review', Nigerian journal of medicine : journal of the National Association of Resident Doctors of Nigeria, 23(4), pp. 335-343. Available at: https://www.scopus.com/inward/record.uri?eid=2s2.0-84922281652\&partnerID=40\&md5=86e299b4a50a9b4306ba60db91e593b4.

20. Ozkomur, A., Erbil, M. and Akova, T. (2013) 'Diamondlike carbon coating as a galvanic corrosion barrier between dental implant abutments and nickel-chromium superstructures', International Journal of Oral and Maxillofacial Implants, 28(4), pp. 1037-1047. doi: 10.11607/jomi.3091.

21. Rodríguez-Padial, L. et al. (2019) 'Trends and Bibliometric Impact of Research Grants of the Spanish Society of Cardiology/Spanish Heart Foundation (2007-2012) [Evolución e impacto bibliométrico de las becas de la Sociedad Española de Cardiología/Fundación Española del Corazón en el periodo 2007-2012]', Revista Espanola de Cardiologia. Ediciones Doyma, S.L., 72(12), pp. 1012-1019. doi: 10.1016/j.recesp.2018.08.013.

22. Rostoker, G. et al. (1986) 'Dermatitis due to orthopedic implants [DERMATOSES D'INTOLERANCE AUX METAUX DES MATERIAUX D’OSTEOSYNTHESE ET DES PROTHESES (NICKELCHROME-COBALT)]', Annales de Dermatologie et de Venereologie, 113(11), pp. 1097-1108. Available at: https://www.scopus.com/inward/record.uri?eid=2-s2.00022844691\&partnerID=40\&md5=87ed793d5522a1086f2cbbc9705409a4.

23. Shahid, I. et al. (2020) 'Characteristics of highly cited articles in heart failure: A bibliometric analysis', Future Cardiology. Future Medicine Ltd., 16(3), pp. 189-197. doi: 10.2217/fca-2019-0016.

24. Thomas, P. et al. (2009) 'Increased metal allergy in patients with failed metal-on-metal hip arthroplasty and peri-implant T-lymphocytic inflammation', Allergy: European Journal of Allergy and Clinical Immunology, 64(8), pp. 1157-1165. doi: 10.1111/j.1398-9995.2009.01966.x.

25. Thomsen, M., Rozak, M. and Thomas, P. (2013) 'Use of allergy implants in Germany: Results of a survey [Verwendung von Allergieimplantaten in Deutschland: Ergebnisse einer Umfrage]', Orthopade, 42(8), pp. 597-601. doi: 10.1007/s00132-012-2032-6.

26. Tran, B. X. et al. (2019) 'The current research landscape of the application of artificial intelligence in managing cerebrovascular and heart diseases: A bibliometric and content analysis', International Journal of Environmental Research and Public Health. MDPI AG, 16(15). doi: 10.3390/ijerph16152699.

27. Ullah, S. et al. (2019) 'Publication trends of Pakistan Heart Journal: A bibliometric study', Library Philosophy and Practice. University of Idaho Library, 2019. Available at: https://www.scopus.com/inward/record.uri?eid=2-s2.0$85072911351 \&$ partnerID $=40 \& \mathrm{md} 5=\mathrm{c} 7 \mathrm{~b} 4 \mathrm{ec} 3 \mathrm{c} 78 \mathrm{fbd} 1 \mathrm{fed} 8 \mathrm{e} 2 \mathrm{e} 7890 \mathrm{fdef} 688$. 